\title{
Determine the E-Learning Competencies Gap of Business Students in the North Central Polytechnic, Nigeria
}

\author{
Edna Ikwubiela Baba \\ Department of Office Technology and Management, The Federal Polytechnic, Idah, Nigeria
}

\begin{abstract}
This study was carried out to determine the e-learning competencies gap of business students in the North Central Polytechnic, Nigeria. To direct the study, two research questions guided the study and two null hypotheses were tested at 0.05 level of significance. The Cronbach Alpha coefficient measure of internal consistency was used to test the reliability value of the instrument. The results of the reliability test were 0.90 , 0.91 . The population of the study comprised 753 students of 2019/2020 HND business students in the North Central, Polytechnics. The study adopted complete enumeration method. A structured questionnaire was developed by the researcher and validated by three experts. The data collected were analyzed using mean and standard deviation to answer the research questions. The t- test was used to test the two null hypotheses. The data analysis revealed that business students in North Central, Polytechnics have competencies gap in e-learning internet and e-learning computer competencies to. Based on these findings, it was recommended that the federal government should provide the institutions with internet facilities so as to strengthen the internet competencies needed for e-learning. It was also recommended that and the accreditation teams of the National Board for Technical Education (NBTE) should revise the syllabus of the Polytechnics to include virtual courses that will be internet-based through a well-established Learning Management System (LMS) tools such as Moodle and Blackboard.
\end{abstract}

Keywords: E-learning, Internet, Computer, Competencies, Polytechnic

DOI: $10.7176 / \mathrm{JEP} / 12-23-04$

Publication date:August $31^{\text {st }} 2021$

\section{Introduction}

The digital information technology has opened a new source for teaching and learning. The internet education has become a major source of learning, often replacing the traditional classroom. The internet and particularly, the social media have made education no longer limited to the four walls of school classrooms. The internet has become one of the vital ways to making available resources for research and learning for both teachers and students to share and acquire information. Technology-based e-learning encompasses the use of the internet and other important technologies to produce materials for learning, teach learners and also regulate courses in an institution (Olutola, 2015, Mbah, 2016 \& Ahmed, 2017).

The internet is a global/worldwide computer network that interconnects a large number of other smaller networks belonging to governments, companies and individuals. The principal purpose of the internet is to allow transfer of data between various types of computer systems. This is ensured by the hardware connected to the global network - computer systems, servers, network hubs and routers, wired and wireless communication channels and software that controls the operation of the hardware (Alamba, 2018).

There has been extensive debate about a common definition of the term e-learning. Bates (2018) and Wasiu et al (2020) referred to e-learning as the use of information and communication technologies to enable the access to online learning/teaching resources. The authors further stated that in its broadest sense, e-learning means any learning that is enabled electronically. The authors however narrowed this definition down to mean learning that is empowered by the use of digital technologies.

Again, Bamerjo (2016) and Schleiler and Reimer (2020) noted that e-learning has transformed from a fullyonline course to using technology to deliver part or all of a course independent of permanent time and place. The authors also asserted that e-learning is the use of new multimedia technologies and the internet to increase learning quality by easing access to facilities and services as well as distant exchanges and collaboration. One of the major characteristics of electronic learning is the use of electronic machines and media to facilitate learning. E-learning, according to David (2017) and Huang et al (2020) is applied in different perspectives, including distributed learning, online-distance learning, as well as hybrid learning. The authors further defined e-learning as the use of information and communication technologies in diverse processes of education to support and enhance learning in institutions of higher education, and includes the usage of information and communication technology as a complement to traditional classrooms, online learning or mixing the two modes.

According to Wentling (2018), the term e-learning refers to the attainment and use of knowledge that are predominantly facilitated and distributed by electronic means. He further opined that the features of e-learning process are chiefly centered on the internet, global sharing and learning resources, information broadcasts and knowledge flow by way of networking courses and lastly, flexibility of learning as computer-generated 
environment for learning to overcome issues of distance and time. Muhammed, Asua and Munnaza (2015) concurred that the internet and World Wide Web have made the computer a dynamic resources in education, providing a new and interactive means of overcoming time and distance to reach learners.

In addition Elvis (2018) and Adeoye et al (2020) argued that the concept of e-learning is proposed based on distance learning, thus a transmission of lectures to distant locations by way of video presentations. However, they claimed that the progression of communications technologies, particularly the internet, did transform distance learning into e-learning. The present age of information technology is becoming quite popular for accessing information of any kind on the internet. Internet provides tremendous opportunities to students, researchers and professionals for getting information on matters related to academic and professional topics and lots more. In this present world, most of the people who have computers around themselves use internet to access information from the World Wide Web, exchange messages and documents and electronic services (Paul, 2018 \& The World Bank, 2020).

The use of ICT in teaching and learning is an already accepted innovation in many developed and developing nations. In the higher education arena, there are shifts in the views of what education is for, with a growing emphasis on the need not only to enable and support the acquisition of knowledge and information, but also to develop the skills and resources necessary to meet up with social and technological changes, and to continue learning throughout life. The move includes student-centered approaches and virtual classroom. There is, however, the need to develop strategies for maximum utilization of this innovation (Harrison, 2017 \& Munce, 2018).

There are two (2) ways to interact with the instructor(s) in an online class. According to Lewis (2017), it can be through synchronous interaction and asynchronous interactions. Synchronous interaction is an online communication that takes place at the same time from different locations. You can either see your instructor virtually via video-feed, hear your instructor's voice, or text to your instructor via a chat-room. You get real-time interaction as if you are talking to someone face-to-face. Skype is an example of a synchronous communication tool for this type of communication. On the other hand, asynchronous interaction occurs at different times. The recipient of your message does not necessarily receive the message immediately. Instead, the recipient can take time to ingest your message and construct a thoughtful response, which is one advantage of asynchronous interaction. Email is an example of this type of interaction. As a computer assisted learning and pedagogy for students' centred and collaborative learning, e-learning could be used to enhance skills and knowledge acquisition among business students.

Business studies is a component of the umbrella business education. Business education is one of the occupation area that are richly provided by vocational and technical education in Nigeria. Business education is planned for training and developing recipients to expose them in the field of business, and as professionals, expanding the way for imparting competencies for economic development in the e-world or society. Similarly, Aquah, in NJoku and Nwachukwu (2019) opined that business education is an educational programme which involves the acquisition of skills, knowledge and competences which make the recipients/beneficiaries proficient in business skills/endeavours. For business students to be equipped with the skills, attitude and competencies needed to meet up with the demand of the global market job, it becomes imperative that the educational system must function optimally and the teachers be professionally equipped to provide the requisite knowledge, skills, attitude, and competencies through the application of e-learning.

Polytechnic education is one of the tertiary levels of education given after secondary school. Polytechnic institutions are largely owned by both federal and state governments. Federal owned polytechnics are those polytechnics owned, financed and managed by the federal government while the state polytechnics are those polytechnics owned, financed and managed by state governments. Ndinechi and Gude (2014) posited that it is a two tier programme of studies that consist of National Diploma (ND) and Higher National Diploma (HND) with one year industrial experience as one of the pre-requisites for HND programme.

In the polytechnic education, business education is offered as a programme of instruction in departments such as Accounting, Marketing and Office Technology and Management. E-learning is supposed to be used by both male and female business students in polytechnics in North Central polytechnic, Nigeria. But, a lot of challenges are witnessed in the utilization of e-learning by business students in North Central polytechnics, Nigeria. According to Okeke (2016), most lecturers and students of business education have not been making effective use of e-learning resources in their academic work. Okeke (2016) and Eze (2016) asserted that there is low level of e-learning awareness in most institutions in Nigeria.

The objectives of polytechnic education, both federal and state owned, as stated in the National Policy on Education (FRN,2013), are to provide full-time course of instructions and training in engineering, other technologies, applied sciences, business and management, leading to the production of trained manpower, to provide the technical knowledge and skills necessary for occupational development in Nigeria as well as to give training and impact necessary skills for the production of skilled personnel who shall be enterprising. It also emphasized a united, strong and self reliant nation. It further stressed the need for acquisition of appropriate 
knowledge and skills necessary for securing paid employment in an establishment or be self-employed. Therefore, well cherished objectives of polytechnic education cannot be achieved if emphasis is not laid on the importance of e-learning skills acquisition in this era of Information technology. For polytechnic education programme to sustain its relevance in providing the needs of individuals and that of the society in the e-world, it must embrace current trends in new technologies application in the academic and economic demands of the society by providing the students with the necessary level of competencies that determine the requirements of the labour market .

Competency is defined by the International Board of Standards for Training, Performance and Instruction in Alfaleh (2017) as the skills, knowledge, and attitudes that enable one to effectively perform the activities of a given occupation or function to the standards expected. It is the ability to perform work, which includes various capabilities associated with performing the teaching profession, reaching a suitable level of perfection. Procedurally, they can be defined in this research as the set of knowledge and skills that make business students in North Central polytechnics, Nigeria effectively qualified for the labour market at the required and expected standards.Amos (2017) defined internet competency as the reflective and conceptual skills needed to engage and take out the relevant contents from the internet. It is also the process of opening a website through the web browser which contains hyperlinks. With the help of these hyperlinks user can go to a new web document in the same or a new window which is known as navigating or surfing the web.

However, competencies are used to refer to the knowledge, skills, abilities, and attributes necessary to perform a job well (De Coi et al in Bezuidenhout, 2018). It is evident that the internet and digitalization of business activities has affected the skills and knowledge required to work in an environment where educators no longer serve mainly as the distributor of contents but become more involved as facilitators of learning and assessors of competencies. Business students, according to Oloja, Adewunmi and Ajisola in Ezeabii, Ile and Ezugwu (2019), need to be exposed to be exposed to ICT facilities and other body of knowledge through elearning in order to be competent and competitive in the world of work. But it seems that there are constraints to the use of e-learning as most of the tertiary institutions seem not to be making proper use of these e-learning resources in teaching (Oloja, Adewunmi \& Ajisola in Ezeabii, Ile \& Ezugwu (2019).

In the same vein, Olukayode (2015) posited that the challenges of e-learning include lack of computers, shortage of internet facilities, students access to e-learning facilities and tools, high cost of software and erratic power supply. Similarly, despite the laudable benefits of e-learning, educators and students are still working with obsolete and crude methods of teaching, use of chalkboard, conventional method of learning, outdated e-learning facilities even in this $21^{\text {st }}$ century.

It was against this background that this study was carried out to determine the e-learning competencies gap of business students in North Central polytechnics, Nigeria, with a view to verifying empirically the extent these students are equipped with the required competencies.

\subsection{Statement of the Problem}

One of the major benefits of employing e-learning for training is related to the flexibility it offers and the ease of adaptation of how the training is delivered to individual learners. Improving the quality of education and training is a critical issue, particularly at a time of educational expansion. To this end, learners are expected to acquire certain e-learning skills in order to excel and compete favourably in the global market where education is pivotal to sustainable development.

In spite of the prospect of e-learning, there seems to be some hurdles still militating against the effective utilization of the e-learning resources in Nigeria as most of the polytechnics seems not to be making use of these e-learning resources in teaching and learning. According to Okeke (2016), most lecturers and students of business education have not been making effective use of e-learning resources in their academic work. This may be due to constraints such as poor policy and project implementation strategies, poor information infrastructure, manpower shortage, lack of knowledge and use of computer aided instruction militate against the effective use of e-learning in North Central polytechnics, Nigeria. If learners are not being adequately exposed to the experiences that will guarantee the total development of their being in the e-world, they would perform below expectation in the digitalized world of work. Hence, there would be competencies gap. Therefore, this study is design to determine the e-learning competencies gap of business students in North Central polytechnics, Nigeria.

\subsection{Objectives of the study}

The major objective of this study is to assess the e-learning competencies gap of business students in the North Central Polytechnics, Nigeria. Specifically the study sought to:

1 determine the internet competencies gap of business students in the North Central polytechnics, Nigeria.

2 determine the computer competencies gap of business students in the North Central polytechnics, Nigeria. 


\subsection{Research Questions}

The following research questions guided the study.

1. What are the e-learning internet competencies gap of business students in the North Central Polytechnics, Nigeria?

2. What are the e-learning computer competencies gap of business students in the North Central Polytechnics, Nigeria?

\subsection{Statement of Hypotheses}

1. There is no significant difference in the mean rating of business students in federal and state owned polytechnics on the e-learning internet competencies gap of business students in the North Central Polytechnics, Nigeria.

2. There is no significant difference in the mean ratings of male and female business students on the e-learning computer competencies gap of business students in the North Central Polytechnics, Nigeria.

\subsection{Research Methodology}

The study adopted a descriptive survey research design which allow the collection of a large amount of data from sizeable population in a highly economical way usually involving the use of questionnaire administered on a sample (Sanders et al 2009). The population for the study comprised 753 Higher National Diploma II business graduating students in polytechnics in North Central, Nigeria. This consists of 274 students from the Federal Polytechnics and 479 students from the state owned polytechnics. The entire population was studied; thus, the study adopted a complete enumeration method because the population size is manageable. A 38-item structured questionnaire was developed from the literature reviewed for the study and utilized for data collection. Each questionnaire item had a five point rating scale of Very High Extent $(\mathrm{VHE}=5)$, High Extent $(\mathrm{HE}=4)$, Moderate Extent $(\mathrm{ME}=3)$, Low Extent $(\mathrm{LE}=2)$, Very Low Extent $(\mathrm{VLE}=1)$. Three experts face validated the instrument. Cronbach alpha coefficient measure of internal consistency was used to determine the reliability of the instrument and a coefficient of 0.83 was obtained. 753 copies of the questionnaire were administered to the respondents by the researcher and two research assistants and 693 copies were retrieved on completion which gave a retrieval rate of $92 \%$. The data generated was analyzed through descriptive statistics of Mean and Standard deviation to answer the research questions. Inferential statistics (t-test) was employed to test the hypotheses at 0.05 level of significance. Any item with a mean score less than 3.50 is considered as a gap while a mean score of 3.50 and above is not a gap.

\section{Data Analysis and Results}

The results of the analysis of data generated were presented and analyzed thus:

\section{Research Question 1}

What are the e-learning internet competencies gap of business students in the North Central Polytechnics, Nigeria?

Data collected in answering research question 1 is presented in Table 1. 
Table 1: Mean ratings and standard deviations of the respondents on e-learning computer competencies gap of business students in North Central polytechnics, Nigeria

\begin{tabular}{|c|c|c|c|c|}
\hline $\mathrm{S} / \mathrm{N}$ & Items & Mean & SD & Decision \\
\hline 1 & Ability to navigate the website and a new link & 3.75 & 1.75 & Not a Gap \\
\hline 2 & Ability to manage bookmarks & 3.45 & 1.59 & A Gap \\
\hline 3 & Ability to set and do minor troubleshooting & 3.25 & 1.66 & A Gap \\
\hline 4 & Ability to connect computer to the internet & 3.86 & 1.76 & Not a Gap \\
\hline 5 & Ability to attach documents and files to e-mail messages & 3.34 & 1.84 & A Gap \\
\hline 6 & Ability to connect to various social communication media & 4.21 & 1.79 & Not a Gap \\
\hline 7 & Ability to download files from the internet & 4.35 & 1.84 & Not a Gap \\
\hline 8 & Ability to upload files to the internet & 2.37 & 0.74 & A Gap \\
\hline 9 & $\begin{array}{l}\text { Ability to use synchronized communication programmes } \\
\text { (Skype - Messenger) }\end{array}$ & 2.85 & 1.41 & A Gap \\
\hline 10 & Ability to use YouTube & 3.45 & 1.60 & A Gap \\
\hline 11 & Ability to use databases & 3.30 & 1.53 & A Gap \\
\hline 12 & Ability to use electronic libraries & 3.37 & 1.67 & A Gap \\
\hline 13 & Ability to work with Internet Explorer - Chrome & 4.15 & 1.89 & Not a Gap \\
\hline 14 & Ability to work with search engines (Google) & 3.92 & 1.76 & Not a Gap \\
\hline 15 & Ability to work with search engines (Yahoo) & 4.75 & 1.79 & Not a Gap \\
\hline 16 & Ability to use e-mail in sending and receiving mails & 3.89 & 1.79 & Not a gap \\
\hline
\end{tabular}

Source: Field Research (2021)

Data in Table 1 revealed that out of the 16 items, item numbers 2,3,5,8,9,10,11, and 12 with means ranging from 2.37 to 3.45 fall within the range of e-learning internet competencies gap while the remaining eight item numbers $1,4,6,7,13,14,15$, and 16 fall within the range of not a gap. The standard deviations for all the items are within the same range indicating that the respondents were homogeneous in their ratings that business students in Polytechnics North Central, Nigeria have e-learning internet competencies gap in the items..

\section{Research Question 2}

What are the e-learning computer competencies gap of business students in the North Central Polytechnics, Nigeria?

Data collected in answering research question 2 is presented in Table 2.

Table 2: Mean ratings and standard deviations of the respondents on e-learning computer competencies gap of business students in North Central polytechnics, Nigeria

\begin{tabular}{lllll}
\hline S/N & Items & Mean & SD & Decision \\
\hline $\mathbf{1 7}$ & Ability to use Chat room & 2.85 & 1.30 & A Gap \\
$\mathbf{1 8}$ & Ability to use social networking & 3.85 & 1.75 & Not a Gap \\
$\mathbf{1 9}$ & Ability to use Forum & 3.30 & 1.52 & A Gap \\
$\mathbf{2 0}$ & Ability to use Blog & 3.47 & 1.54 & A Gap \\
$\mathbf{2 1}$ & Ability to use audio conferencing & 3.45 & 1.51 & A Gap \\
$\mathbf{2 2}$ & Ability to use video conferencing & 3.34 & 1.62 & A Gap \\
$\mathbf{2 3}$ & Ability to work with Window Operating System & 4.13 & 1.85 & Not a Gap \\
$\mathbf{2 4}$ & Ability to work with printer & 3.76 & 1.77 & Not a Gap \\
$\mathbf{2 5}$ & Ability to work with scanner & 3.48 & 1.50 & A Gap \\
$\mathbf{2 6}$ & Ability to work with speakers & 3.40 & 1.68 & A Gap \\
$\mathbf{2 7}$ & Ability to work with microphone & 3.35 & 1.58 & A Gap \\
$\mathbf{2 8}$ & Ability to download programme & 3.62 & 1.26 & Not a Gap \\
$\mathbf{2 9}$ & Ability to use antivirus programme & 3.45 & 1.50 & A Gap \\
$\mathbf{3 0}$ & Ability to transfer documents to PDF format & 2.55 & 0.68 & A Gap \\
$\mathbf{3 1}$ & Ability to work with video files & 2.95 & 1.08 & A Gap \\
$\mathbf{3 2}$ & Ability to work with voice recording software & 2.75 & 1.43 & A Gap \\
$\mathbf{3 3}$ & Ability to work with data show programmes & 2.75 & 0.44 & A Gap \\
$\mathbf{3 4}$ & Ability to organize and manage files on computer system & 3.59 & 1.42 & Not a Gap \\
$\mathbf{3 5}$ & Ability to delete files and programmes & 3.79 & 1.77 & Not a Gap \\
$\mathbf{3 6}$ & Ability to use Excel programme & 3.78 & 1.66 & Not a Gap \\
$\mathbf{3 7}$ & Ability to use Word Processing programmes & 3.75 & 1.75 & Not a Gap \\
$\mathbf{3 8}$ & Ability to use PowerPoint programme & 3.70 & 1.49 & Not a Gap \\
\hline
\end{tabular}

\section{Source: Field Research (2021)}

Data in Table 2 revealed that out of the 22 items, item numbers 17,19,20,21,22,25,26,27, 29,30, 31,32 and 33 with means ranging from 2.55 to 3.48 fall within the range of competencies gap while the remaining eight 
item numbers $18,23,24,28,34,35,36,37$, and 38 fall within the range of not a gap. The standard deviations for all the items are within the same range indicating that the respondents were homogeneous in their ratings that business students in North Central polytechnics, Nigeria have e-learning computer competencies gap.

\section{Hypothesis 1}

There is no significance difference in the mean ratings of business students in federal and state owned polytechnics on the e-learning internet competencies gap of business students in North Central polytechnics, Nigeria.

Table 3: t-test statistics on mean scores of business students in federal and state owned polytechnics on the e-learning internet competencies gap of business students in polytechnics in North Central, Nigeria

\begin{tabular}{llcccccr}
\hline $\begin{array}{l}\text { Variables } \\
\text { (Institutions) }\end{array}$ & N & Mean & SD & df & t-cal & t-tab & Remark \\
\hline Federal & 274 & 4.04 & 1.01 & 692 & 1.33 & 1.96 & Not Sig. \\
State & 479 & 3.99 & 0.97 & & & &
\end{tabular}

Data in Table 3 of the t-test analysis showed that the t-cal value of 1.33 is less than the t-critical value of 1.96 at 0.05 level of significance and 692 degree of freedom. Hence, the null hypothesis that there is no significance difference in the mean ratings of business students in federal and state owned polytechnics on the elearning internet competencies gap is accepted.

Hypothesis 2

There is no significance difference in the mean ratings of male and female business students on the e-learning computer competencies gap of business students in North Central polytechnics, Nigeria.

Table 4: t-test statistics on mean scores between male and female business students on the e-learning computer competencies gap of business students in North Central polytechnics, Nigeria

\begin{tabular}{lccccccc}
\hline $\begin{array}{l}\text { Variables } \\
\text { (Gender) }\end{array}$ & N & Mean & SD & df & t-cal & t-tab & Remark \\
\hline Male & 351 & 3.76 & 1.09 & 692 & 1.58 & 1.96 & Not Sig. \\
Female & 342 & 3.78 & 1.07 & & & &
\end{tabular}

Table 4 of the t-test analysis revealed that the t-cal value of 1.58 is less than the t-critical value of 1.96 at 0.05 level of significance and 692 degree of freedom. Hence, the null hypothesis which states that there is no significance difference in the mean ratings of male and female Business students on the e-learning computer competencies gap is accepted.

\section{Discussion of Findings}

The findings of the study according to the first research question showed that there is e-learning internet competencies gap of business students in North Central polytechnics, Nigeria. The identified e-learning internet competencies include items numbers 2 (ability to manage bookmarks), 3 ability to set and do minor troubleshooting, 5 (ability to attach documents and files to e-mail messages), 8 ( ability to upload files to the internet), 9 (ability to use synchronized communication programmes - Skype Messenger), 10 (ability to use YouTube ), 11(ability to use database), and 12(ability to use electronic libraries), with means ranging from 2.37 to 3.45. This is in line with the finding of a study carried out by Okeke (2016), which revealed that a lot of challenges are witnessed in the utilization of e-learning Nigeria. according to Okeke (2016), most lecturers and students of business education have not been making effective use of e-learning resources in their academic work. Okeke (2016) and Eze (2016) also found that there is low level of e-learning awareness in most institutions in Nigeria. also the finding agreed with the study of Azubuike and Offordile's study that most schools lack some of the e-learning devices and the problems facing the use of e-learning network in teaching include poor power supply, financial problems, low computer literacy level, low quality and expensive nature of VSAT connections.

The result of the study in respect to the second research questions revealed that business students in North Central polytechnic, Nigeria have e-learning computer competencies gap in item numbers 17(ability to use Chat room), 19 (ability to use Forum), 20 (ability to use Blog), 21 (ability to use Audio), 22 (ability to use Video), 25 (ability to work with scanner), 26 (ability to work with Speakers), 27 (ability to work with Microphone), 29 (ability to use antivirus), 30 (ability to transfer documents to PDF format), 31 (ability to work with video files), 32(ability to work with voice recording software), and 33 (ability to work with data show programmes) with means ranging from 2.55 to 3.48 . This findings is in consonance with the findings of Olukayode (2015) which revealed that the challenges of e-learning include lack of computers, shortage of internet facilities, students access to e-learning facilities and tools, high cost of software and erratic power supply. 
The null hypotheses showed that there was no significant difference in the mean ratings of business students in Federal and state owned polytechnics regarding the e-learning internet competencies gap. Also, it showed that there was no significant difference in the mean ratings of male and female business students in North Central polytechnics, Nigeria polytechnics regarding the e-learning computer competencies gap. This implies that business students in North Central polytechnics, Nigeria have competencies gap in e-learning internet and computer competencies.

\section{Conclusion}

E-learning is a large and growing market with great potential in higher institution of learning. The features of elearning process are mainly centered on the internet, global sharing and learning resources, information broadcasts and knowledge flow by way of networking courses. In order to maximize this potential, e-learning is required to be adopted in schools for positive impact on teaching, learning and research. Business students in particular are required to possess e- learning competencies in order to prepare them to participate in the technologically driven global environment.

\section{Recommendations}

Based on the findings of this study, the following recommendations were made:

1. The federal government should strengthen the institutions with internet facilities by providing fund to improve their ICT facilities and provide free internet access so as to enable digital instruction and learning between business teachers and the students thereby bridging the gap of e-learning competencies of business students.

2. The accreditation teams of the National Board for Technical Education (NBTE) should revise the curriculum in educational technology for Polytechnics to include a web-based programme. This will make them better qualified and suitable to promote the digital learning activities of educational institutions and to prepare students for the labour market.

\section{References}

Adeoye, I.A.,Adanklin, A. (2020). Covid-19 and e-learning in Nigerian tertiary education system Experience. International Journal Res. Innov. Appl. Sci. 5 (5).

Ahmed,O. (2017). Quality models in online and open education around the globe. Retrieved from: http://www.pedocs.de/frontdoor.php on 29th March, 2018.

Alamba, I. O. (2018). Roles and competencies for distance education programmes in higher education institutions. Bamide Publishing Press.

Alfaleh, M.A. (2017). Extent of e-learning competencies by students of Princess Nourah bint Abdulrahman University necessary for accessing the labour market. Asian Education Studies,. 2( 2). Retrieve from http://aes.julypress.com, on 17 May, 2021.

Amos, K. (2017). Evaluating the virtual classroom: Perspectives on a new environment. New York: Praeger Publishers.

Azubuike, O.C. \& Offordile, S. (2015). Strategy for improving the use of electronic teaching and learning (elearning) in agric science and home economics in tertiary institutions of Anambra State, Nigeria. Proceedings of the $1^{\text {st }}$ International Technology, Education and Environment Conference (c) Africa Society for Science Research (ASSR), 1(1), 402-409.

Bamerjo, P. (2016). An introductory approach to online education. Enugu: Donsinbad Publishing Press.

Bates, R. (2018). Learning about online learning: An approach to staff development for university teachers. Australian Journal of Educational Technology, 15(3), 2017- 211.

Bezuidenhout, A. (2018). Analysing the importance-competence gap of distance educators with the increased utilization of online learning strategies in a developing world context. InternationalReview of Research in Open and Distributed Learning, 19(3). 263-281. Retrieved from http://scholar.google.co.za on 21 May 2021

David, B. (2017). Visual interaction: Design factors affecting students' satisfaction and perceived learning in asynchronous online courses. Journal of Distance Education, 22(2), 306 - 320.

Elvis, E. (2018). Implementing e-learning programmes for higher education: A review of literature. Journal of Information Technology Education, 3(1), 95 - 110.

Eze, F.O. (2016). Teachers' perception on the use of computer aided instruction in teaching business studies students in upper basic education in Orumba South L.G.A. of Anambra State. Unpublished B.Sc project report presented to the Department of Vocational Education University of Science and Technology, Enugu.

Ezeabii, I.C., Ile, C.M. \& Ezugwu, S.K. (2019). Improving e-learning among business education students in public universities in South-East, Nigeria. Nigeria Journal of Business Education. 6(1), 207-216.

Federal Republic of Nigeria (2013). .National policy on education. Abuja: NERDC Press. 
Harrison, C. (2017). The need for digital competence. Chicago: Lyceum Press.

Huang, R.H., Liu, D.J., Tlili, A., Yang, J.F., Wang, H. (2020). Handbook on facilitating flexible learning during disruption. The Chinese experience in maintaining undisrupted learning in covid-19 outbreak. Retrieved from link.springer.com on $13^{\text {th }}$ April, 2021.

Lewis, A.(2017). Exploring collaborative online learning. Journal of Asynchronous Learning Networks, 5(1), 21 -34 .

Mbah, C.N. (2016). Utilizing ICT in the teaching and learning programme of colleges of education in Kaduna: The Learner' Perception, Journal of Research and Development 2(1), 78-87.

Muhammed, T.A., Asua, S. \& Munnaza, A. (2015). Teachers perception and needs towards the use of e-learning in teaching of physics in secondary level of Pakinstan. American Journal of Educational Research 3(5), 1045-1051.

Munce, O. (2018). Interactions in online education: Implications for theory and practice. London: Sage Publisher.

Ndinechi, G.I. \& Gude, A.G. (2014). Self-assessment on word processing and spreadsheet proficiency by office technology and management students in north-west Nigerian polytechnics. Nigerian Journal of Business Education 1(3), 313-321.

Njoku, J.U. \& Nwachukwu, J.C. (2019). Application and challenges of e-learning in business education programme in universities in South-East, Nigeria. Nigeria Journal of Business Education. 6(1),198-206.

Okeke, A.F. (2016). Influence of new technologies on the teaching of business education in tertiary institutions in Anambra State. Unpublished B.Sc project report presented to the Department of Vocational Education Odemeqwu Ojukwu University, Anambra State.

Olukayode, S.A. (2015). Challenges and prospects of e-learning at National Open University of Nigeria. Journal of Education and Learning, 9(3), 207-216.

Olutola, A.T., Olatoye, O.O. (2015). Challenges of e- learning in Nigerian University Education and Social Research. 5(1).

Paul, S. H. (2018). Teaching and learning internet skills. Journal of Science and Technology, 78, 5-13.

Richard, D. (2017). E-learning strategies for delivering knowledge in the digital age. New York: Hill.

Saunders, M.L., Lewis, P. \& Thornhill, A. (2009). Research methods for business students (5 ${ }^{\text {th }}$ ed.). Harlow, England: Prentice Hall.

Sehleicher, A., Relmers, F. (2020). Schooling Disrupted, Schooling Rethought. How the covid-19 pandemic is changing education. OECD.

The World Bank (2020). How countries are using Edtech (including online learning, radio, television, texting) to support access to remote learning during the covid-19 pandemic. Retrieve from www.worldbank.org $20^{\text {th }}$ March, 2021.

Wasiu, O.O., Ayodeji, M.O., Maryam, A.O., Abayomi, O.A.,Rafiat, B.F. (2020). Prospects and Limitations of elearning application in Private tertiary institutions amidst covid-19 lockdown in Nigeria. Heliyon, 6.

Wetling, B. (2018). E-learning - A review of literature. Berkeley: University of California Press.

Yanti, H. Setiawan, A..Nurhabibah, A. and Yannnuar, R. (2018).Teachers perception about the use of e-learning in educational activities. Retrieved from: http://www.iopscience.iop.org/aritcle on 10th June, 2021. 